\title{
Sparse coding models demonstrate some non-classical receptive field effects
}

\author{
Mengchen Zhu ${ }^{1 *}$, Christopher J Rozell ${ }^{2}$ \\ From Nineteenth Annual Computational Neuroscience Meeting: CNS*2010 \\ San Antonio, TX, USA. 24-30 July 2010
}

Non-classical receptive field ( $\mathrm{nCRF}$ ) effects include several response properties in V1 neurons not explained by a linear-nonlinear (LN) receptive field model, but instead requiring significant interactions between V1 neurons. Using a sparse coding model $[1,2]$ and bar and grating stimuli, simulated physiology experiments were carried out that replicated several nCRF phenomena reported previously in neurophysiology experiments. These include: end-stopping [3] (Fig. 1), contrast invariance of orientation tuning [4] (Fig. 2), radius, orientation, and contrast tunings of surround suppression $[5,6]$ (Figs. 3, 4, 5). The results suggest that a sparse coding model can explain many of the nonlinear effects in V1 cells, and is therefore a reasonable candidate for a functional model of striate cortex.

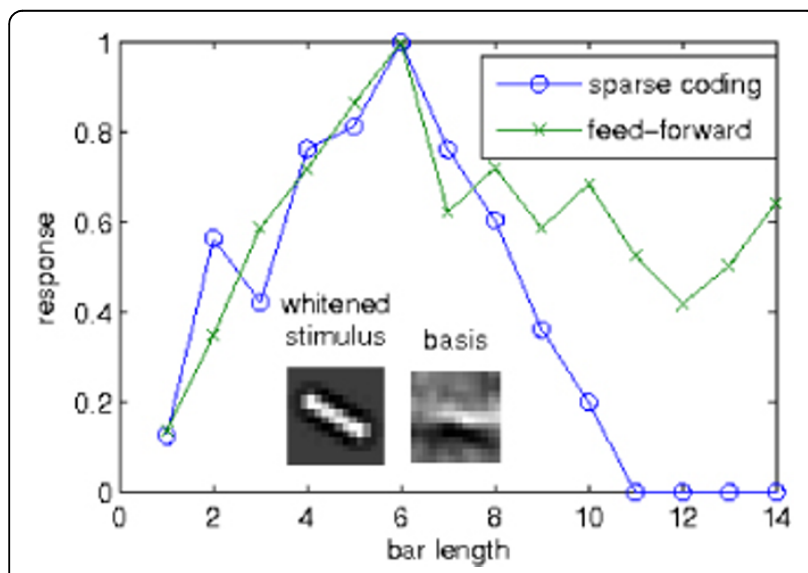

Figure 1 End-stopping. Comparison with a LN model.

\footnotetext{
* Correspondence: mczhu@gatech.edu

'Department of Biomedical Engineering, Georgia Institute of Technology, Atlanta, GA 30332, USA
}

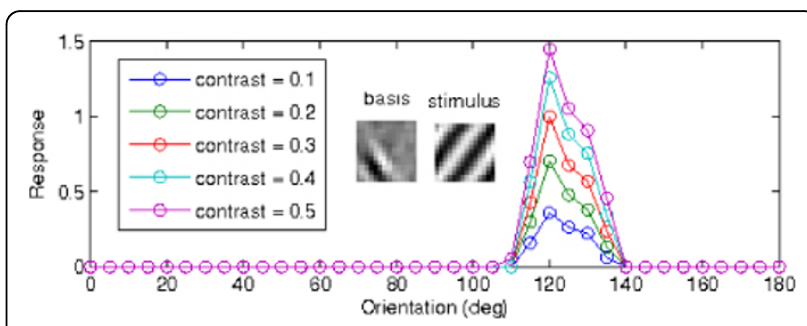

Figure 2 Contrast invariance of orientation tuning.

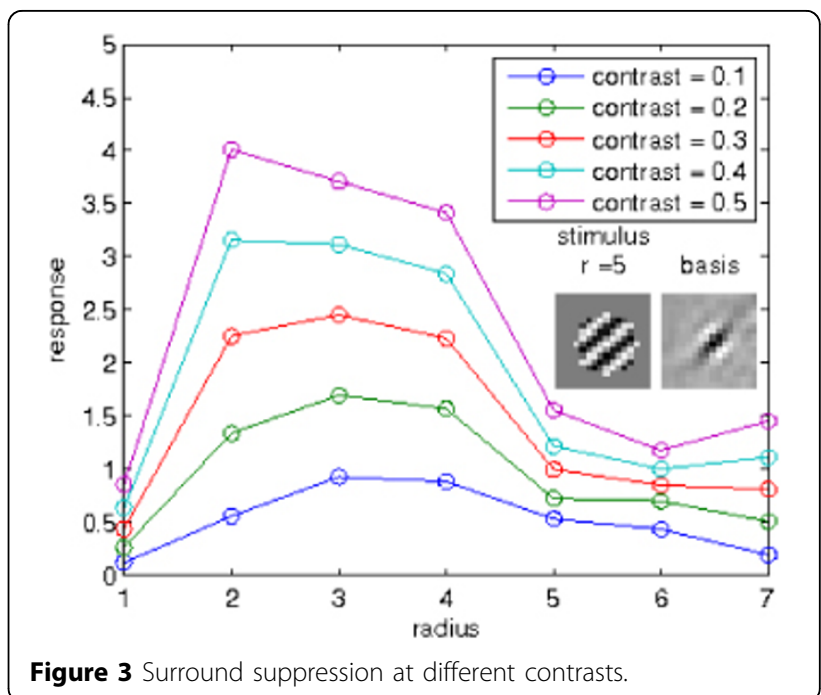

Author details

'Department of Biomedical Engineering, Georgia Institute of Technology,

Atlanta, GA 30332, USA . 'Department of Electrical and Computer

Engineering, Georgia Institute of Technology, Atlanta, GA 30332, USA.

Published: 20 July 2010 


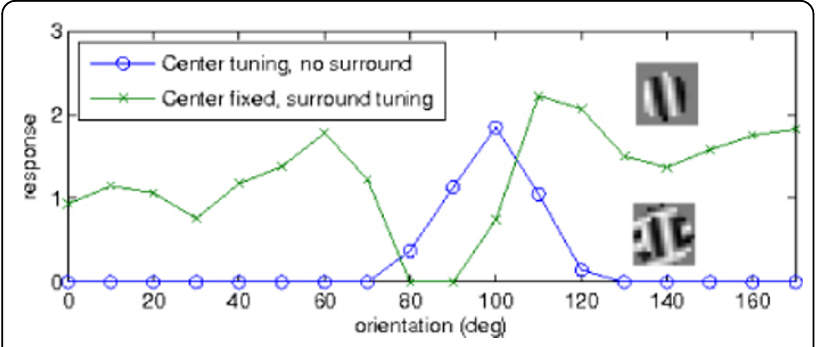

Figure 4 Orientation tuning of surround suppression.

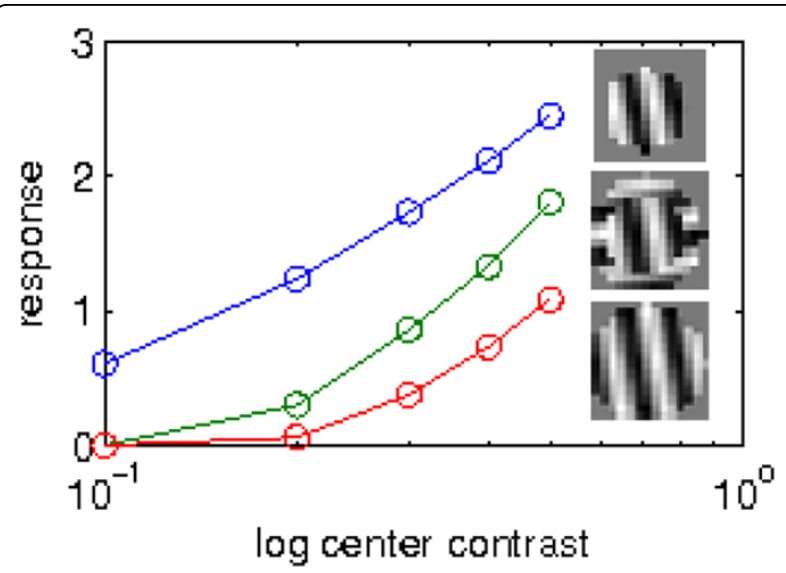

Figure 5 Surround orientation influences contrast tuning.

\section{References}

1. Rozell C, Johnson D, Baraniuk R, Olshausen B: Sparse coding via thresholding and local competition in neural circuits. Neural computation 2008, 20:2526-2563.

2. Olshausen B, Fteld D: Sparse coding with an overcomplete basis set: A strategy employed by V1? Vision research 1997, 37:3311-3325.

3. Bolz J, Gilbert C: Generation of end-inhibition in the visual cortex via interlaminar connections. Nature 1986.

4. Skottun B, Bradley A, Sclar G, Ohzawa I, Freeman R: The effects of contrast on visual orientation and spatial frequency discrimination: a comparison of single cells and behavior. Journal of Neurophysiology 1987, 57:773.

5. Cavanaugh J, Bair W, Movshon J: Nature and interaction of signals from the receptive field center and surround in macaque $\mathrm{V} 1$ neurons. Journal of Neurophysiology 2002, 88:2530.

6. Cavanaugh J, Bair W, Movshon J: Selectivity and spatial distribution of signals from the receptive field surround in macaque V1 neurons. Journal of Neurophysiology 2002, 88:2547.

\section{Submit your next manuscript to BioMed Central} and take full advantage of:

- Convenient online submission

- Thorough peer review

- No space constraints or color figure charges

- Immediate publication on acceptance

- Inclusion in PubMed, CAS, Scopus and Google Scholar

- Research which is freely available for redistribution

Submit your manuscript at www.biomedcentral.com/submit 